\title{
Intestinal inflammation and the gut microflora
}

\author{
Derek M McKay PhD
}

DM McKay. Intestinal inflammation and the gut microflora. Can J Gastroenterol 1999;13(6):509-516. The idea that the enteric microflora play a role in the pathogenesis or pathophysiology of inflammatory bowel disease (IBD) is not new. Indeed, identification of an infective cause for chronic IBD, and particularly for Crohn's disease, has been the focus of extensive research efforts. During the 1990s, there has been a noticeable re-emergence of interest in the link between bacteria and functional bowel disorders, and the value of antibiotic therapy to treat gut inflammatory disorders. A variety of experimental evidence from both laboratory model systems and clinical investigations is reviewed with respect to a pivotal role for enteric bacteria in gut inflammation. The voluminous scientific literature on this subject precludes any comprehensive synopsis of the area; instead, pertinent studies are cited to illustrate the ability of bacteria and their products to evoke or exacerbate gut inflammation.

Key Words: Gut inflammation; Inflammatory bowel disease; Microflora

\section{Inflammation intestinale et microflore entérique}

RÉSUMÉ : L'idée que la microflore entérique puisse jouer un rôle dans la pathogenèse et la physiopathologie de la maladie inflammatoire de l'intestin (MII) n'est pas nouvelle. En effet, l'étiologie infectieuse possible des MII chroniques et particulièrement de la maladie de Crohn a été au centre de beaucoup de travaux de recherches approfondies. Au cours de l'année 1990, on a noté un intérêt renouvelé à l'endroit du lien entre bactéries et dysfonction intestinale et l'utilité de l'antibiothérapie dans le traitement des maladies inflammatoires de l'intestin. Diverses expériences tirées de modèles élaborés en laboratoire et en recherche clinique sont passées en revue du point de vue du rôle central des bactéries entériques dans l'inflammation intestinale. L'abondance des documents scientifiques sur le sujet nous empêche de procéder à un synopsis complet du domaine. Nous citons plutôt les études pertinentes afin d'illustrer l'aptitude des bactéries et de leurs produits à susciter ou à exacerber l'inflammation intestinale.
$\mathrm{O}$ ver the past few years there has been a resurgence in interest in the putative involvement of bacteria in the pathogenesis and pathophysiology of chronic idiopathic gut disorders, such as inflammatory bowel disease (IBD) and irritable bowel syndrome. It is clear that the presence of the commensal microflora is critical for normal gut function $(1-3)$. Thus, when considering a role for the enteric microflora in disease, it is important to draw a distinction between pathogenic bacteria that may sporadically gain access to the intestine and situations in which the normal immune nonresponsiveness (or tolerance) has been replaced by a state in which the immune system is responsive to organisms that normally have a commensal status.

Recognizing that the commensal microflora is a crucial element in normal gut development and function, the primary goals of this review are to provide an overview of the data that implicate bacteria in the pathophysiology of gut in- flammation and to highlight research directions that will enhance the current understanding of how bacteria and bacterial products can affect the intestine. Before considering the role of bacteria in inflammation, it must be emphasized that genetic predisposition, enhanced enteric permeability and immune dysregulation are also likely key elements in the IBD experienced by cohorts of patients. The following discussion does not discount the value of continued research aimed at defining the role of these other factors in the pathophysiology of enteric inflammatory disease.

\section{ANIMAL MODELS OF GUT INFLAMMATION}

A number of pieces of circumstantial evidence suggest a role for bacteria in enteric inflammation. These include the observations that IBD tends to occur in the region with the greatest bacterial load, that the histological appearance of ulcerative colitis is similar to that caused by Campylobacter

This mini-review was prepared from a presentation made at Canadian Digestive Diseases Week, March 1 to 8, 1998, Banff, Alberta

Intestinal Disease Research Programme, McMaster University, 1200 Main Street West, Hamilton, Ontario L8N 325

Correspondence and reprints: Dr Derek M McKay, Intestinal Disease Research Programme, HSC-3N5, Department of Pathology,

McMaster University, 1200 Main Street West, Hamilton, Ontario L8N 325. Telephone 905-525-9140 ext 22588, fax 905-522-3454,

e-mail mckayd@fhs.McMaster.ca

Received for publication December 3, 1998. Accepted December 9, 1998 
jejuni infection, that Crohn's disease is remarkably similar to Johne's disease (caused by Mycobacterium paratuberculosis) in ruminants and that the levels of antibodies against intestinal bacteria are elevated in patients with IBD (reviewed in 4,5).

Analyses of a variety of models of spontaneous colitis and enterocolitis (6) have corroborated the hypothesis that bacteria can potentiate and/or initiate enteric inflammation. Mice lacking interleukin (IL)-2 (7) or IL-10 (8), and severe combined immunodeficient mice administered splenic $\mathrm{CD}_{45 \mathrm{RB}^{\text {high }}} \mathrm{CD}^{+} \mathrm{T}$ cells (ie, naive T cells) (9) all spontaneously develop colitis. Despite the varied immune abnormalities, these models have some commonality. First, the pathology is T cell-dependent and is dominated by an IL-12 driven Thelper 1 cell (Th1) response (10-14). Second, in all instances the colitis is either absent or significantly reduced in severity if the animals are maintained in a germ-free environment. These findings provide compelling evidence implicating enteric bacteria in the pathophysiology of gut inflammation. A recently reported novel murine model of colitis provided very similar data: up to $50 \%$ of mice lacking the multiple drug resistance gene, $m d r l a$, and housed in specific pathogen-free facilities were found to spontaneously develop colitis (15). The colitic mice had a fourfold increase in mucosal T cells, which were predominantly $\mathrm{CD} 4^{+}$cells, and the incidence of colitis was significantly reduced by antibiotic treatment (15).

Other model systems can also be cited in support of a role for bacteria in gut inflammation. In the dextran sodium sulphate model, colitis is associated with an increase in Enterobacteriaceae and Staphylococcus species in the gut $(16,17)$. The $\mathrm{C} 3 \mathrm{H} / \mathrm{HeJBir}$ mouse develops a colitis that appears to be due to Th1 cells that are reactive to conventional antigens derived from the enteric microflora (18). Transgenic rats expressing the HLA-B27 antigen and human beta2-microglobulin display spontaneous colitis that does not develop in germ-free animals (19). Luminally derived Bacteroides species have been implicated as etiological agents in this model (20). Also, 2,4,6-trinitrobenzene sulphonic acid-induced colitis in rats is mild in the absence of gut flora, particularly anaerobic bacteria (21).

Collectively, these models suggest that perturbations in the immune system and reactions directed against commensal bacteria or their products can precipitate as enteric inflammation. In this context, Duchmann and co-workers (22) reported that $\mathrm{T}$ cells isolated from resected gut tissue from some patients with Crohn's disease recognized and responded to antigens derived from the patients own gut flora. This immune responsiveness to autologous bacteria was not observed when mucosal $\mathrm{T}$ cells from control patients were examined (22). Other reports also show that mucosal T cells from patients with Crohn's disease have an increased reactivity against microbial antigens $(23,24)$. Similar findings using the murine-2,4,6-trinitrobenzene sulphonic acid model of colitis and control mice have been reported (25), and mucosal $\mathrm{T}$ cells isolated from $m d r l a^{-1-}$ mice with active colitis proliferated in response to antigens from their commensal microflora (15).
The animal models discussed above approximate, to some degree at least, Crohn's disease. The T cell receptor (TcR)- $\alpha$ chain knockout mouse develops a disease that is more like ulcerative colitis in its histopathology and is accompanied by increased IL-4 expression, a Th2 cytokine (26). Appendectomy can protect against the spontaneous colitis developed by the TcR- $\alpha$ knockout mouse, and data have been presented that indicate the interaction of commensal bacteria with the immune system (ie, appendix lymphoid tissue) in the induction of colitis (27).

All of the cited animal models of intestinal inflammation have another striking similarity with human IBD - in no instance has any specific pathogen been identified. Infectious agents, notably the measles virus (paramyxovirus) and M paratuberculosis, have been touted as causes of IBD (4). While infection with these organisms can be correlated with Crohn's disease in some patients (28), this is certainly not a universal observation (29).

Despite the fact that considerable research efforts have failed to elucidate a cause for IBD (or even a consensus opinion on a putative infectious etiology of IBD), it is nevertheless premature to dismiss the possibility that IBD is due to a specific pathogen(s), particularly in light of the association between Helicobacter pylori and the pathogenesis of an array of gastric disorders (infection with Helicobacter hepaticus or Helicobacter bilis enhances disease in the CD45RB high $\mathrm{CD}^{+}$ $\mathrm{T}$ cell transfer model of colitis [30,31]; neither agent is suggested as the cause of human IBD) (Figure 1A).

Analyses of animal models of gut inflammation have consistently revealed an intimate association between the enteric microflora and inflammation, and this correlates, at least to some degree, with a variety of clinical observations. However, it would be remiss to overlook a small number of studies that suggest minimal or no involvement of microorganisms in the exacerbation of IBD (32). Because the identification of a specific etiological agent in human IBD has not been forthcoming, it is appropriate to consider more fully the role of bacterial products in the onset or exaggeration of inflammatory diseases in the gut.

\section{BACTERIAL PRODUCTS AS PROINFLAMMATORY STIMULI}

Numerous bacterial products are potent stimuli of immune activity. Thus, a bacterial component(s), rather than a specific pathogen, may elicit an intestinal inflammatory response that progresses to chronic disease. In this context, subserosal injection of streptococci cell wall-derived peptidoglycan-polysaccharides (PG-PS) results in a granulomatous inflammation in genetically susceptible rats (33); PG-PS have been detected immunocytochemically in the bowel wall of some patients with Crohn's disease (34), and anti-PG-PS antibodies can be elevated in the serum of some patients with Crohn's disease (35). Moreover, lipopolysaccharide and the tripeptide formyl-met-leu-phe (fMLP) are ubiquitous bacterial products, and both have been implicated in enteric inflammation (36). For example, neutrophils isolated from patients with Crohn's disease have 
increased receptor expression for $\mathrm{MLP}$ and are more responsive to fMLP (37). Also, monocytes recruited to the inflamed intestine have enhanced expression of the lipopolysaccharide-receptor, CD14 (38), and monocytes isolated from patients with Crohn's disease release increased amounts of toxic oxygen metabolites when stimulated (39). In the latter scenario, lipopolysaccharide was implicated as the factor that primed the monocytes for enhanced reactivity. These examples indicate that bacterial products can contribute to the inflammatory process; however, it is unclear whether in the absence of other confounding factors (eg, a leakier gut to facilitate excessive entry to the mucosa) these products can initiate disease.

A group of small bacterial peptides have recently been characterized and designated as superantigens by virtue of their ability to stimulate up to $25 \%$ of T cells $(40,41)$. Superantigens are synthesized by a variety of species of bacteria (and other pathogens) (42), and activate $\mathrm{T}$ cells by crosslinking an outside domain of the beta-chain of the TcR with the major histocompatibility class II (MHC II) molecule on antigen-presenting cells. This results in a polyclonal expansion of T cells that have a common TcR- $\beta$ chain but different antigen specificity. Juxtaposing these data with the pivotal role that $\mathrm{T}$ cells play in the induction and regulation of inflammation, bacterial superantigens must be viewed as potential proinflammatory stimuli. Skewing in the expression of the TcR- $\beta$ chain implicates bacterial superantigens of unknown identity in the pathophysiology of inflammatory and autoimmune disorders such as rheumatoid arthritis, multisystem vasculitis (Kawasaki disease) and diabetes (43. 46).

Recently, a number of investigations have shown $\mathrm{T}$ cell clonal expansion in cohorts of patients with Crohn's disease, suggesting prior exposure to a superantigen(s) $(47-49)$ and the possibility that superantigens may be involved in IBD (50). Enteric effects of the prototypic bacterial superantigen, Staphylococcus aureus enterotoxin B (SEB), were documented in the 1960s when administration of crude $S$ aureus extracts or crude SEB preparations were administered to dogs or Rhesus monkeys $(51,52)$. This resulted in diarrhea and various degrees of intestinal histopathology including disruption of the normal gut architecture, mucus production, epithelial degeneration and a mononuclear cell infiltrate (53). Subsequently, Lionetti et al (54) showed that in vitro application of SEB to human fetal intestinal explants caused significant tissue damage that was correlated with IL-2 and interferon-gamma production, and was prevented by treatment with the immunosuppressive agent tacrolimus (FK 506) (54). It has been shown that $T$ cell activation by SEB (and an unrelated bacterial superantigen, Yersinia pseudotuberculosis mitogen [55]) results in decreased barrier function and diminished ion transport in monolayers of the human colonic T84 epithelial cell line in vitro (56). Interferongamma and tumour necrosis factor-alpha were implicated in the epithelial dysfunction, which was partially ameliorated by addition of transforming growth factor-beta or IL-10 to the coculture well (57). These findings implicate Th1-

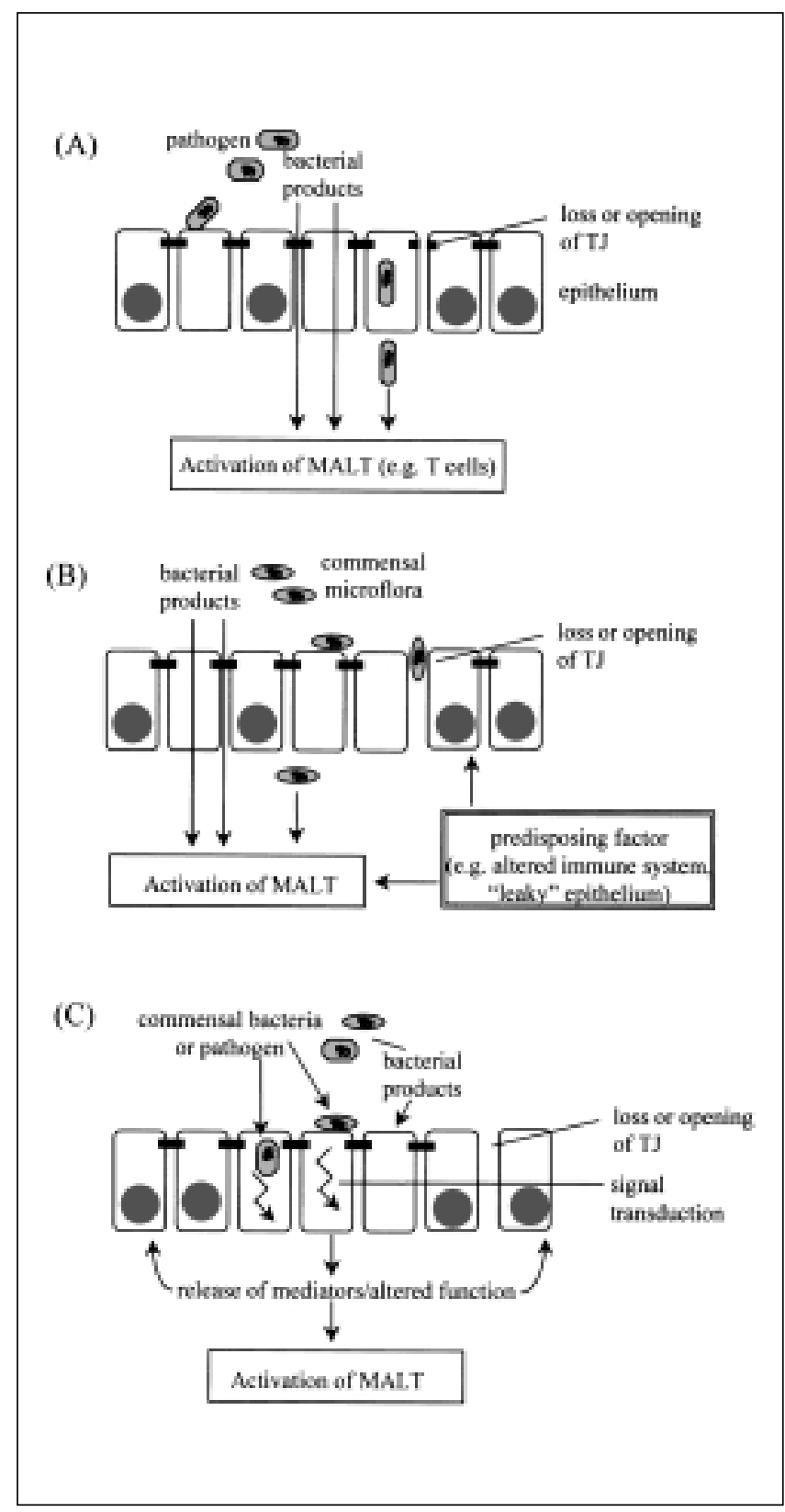

Figure 1) Three models are presented in which bacteria can elicit or potentiate gut inflammation. These models are not mutually exclusive. A A pathogenic bacterium gains access to the intestine and attaches to or invades the epithelium. The pathogen or bacterial products enter the mucosa and elicit an immune response in the mucosa-associated lymphoid tissue (MALT). This results in the production of proinflammatory cytokines, destructive enzymes and other mediators that modulate the immune response and regulate the activity of other cells such as the enterocyte (ie, opening of the paracellular space by affecting the tight junctions [TJ]) and fibroblasts and muscle cells (not shown). B A predisposing factor affects the MALT or the epithelium, which allows commensal microflora or products from these organisms to elicit an immune response that is translated into active inflammation as described for scenario A. C Either pathogenic or commensal (presumably in the context of other perturbations) bacteria or their products directly affect the epithelium, resulting in an activated phenotype. Following a series of signal transduction events, epithelial function is altered, as is the expression of surface molecules and the enterocyte secretes messenger molecules. Epithelial-derived mediators may have autocrine effects on neighbouring enterocytes and paracrine effects on other stromal cells. The MALT is activated or its activity modulated resulting in inflammation 
dominated events in this reductionist model of T cell-driven alterations in epithelial permeability and ion transport function. These data have been complemented by in vivo studies showing that low dose (5 to $100 \mu \mathrm{g}$ ) SEB evokes a murine enteropathy that is characterized by subtle changes in jejunal morphology, a $\mathrm{CD}^{+} \mathrm{T}$ cell infiltrate and reduced responsiveness to prosecretory stimuli $(58,59)$. Diarrhea was evident in the superantigen-treated mice, and the enteric histopathology and functional abnormalities had resolved by $48 \mathrm{~h}$ after treatment.

In summary, a variety of known bacterial products (and others that await characterization [60]) have the ability to elicit acute inflammatory responses and impair normal gut function. Whether these agents initiate disease, convert subclinical conditions to conspicuous disease symptomatology, exaggerate existing disease or evoke relapses in disease activity remains to be determined. The assessment of the impact of proinflammatory bacterial products in laboratory models of spontaneous or induced colitis may provide some insights into these issues (Figure 1B). Additionally, it is essential that the normal and aberrant immunoregulatory pathways evoked in response to agents such as lipopolysaccharide, fMLP and superantigens be precisely defined so that effective therapies can be devised and applied to conditions in which these bacterial products are implicated.

\section{DIRECT BACTERIAL EFFECTS ON THE INTESTINAL EPITHELIUM}

Elucidation of the cooperative activity of diverse cell types in homeostatic processes has revealed that nonimmune cells have the capacity to modulate immune responses. The epithelial cell stands as sentinel at the boundary of mucosal surfaces, and abundant evidence shows that this cell is not merely a passive player in innate immunity, but that it can respond specifically to mediators produced in the mucosa (61) and synthesize a plethora of messenger molecules (62). (Other stromal cells such as fibroblasts and muscle cells can also be activated by immune mediators and also have the potential to influence the individual's response to antigen and/or infection $[63,64]$.)

The immunostimulatory or proinflammatory effects of bacterial products and how these impinge on gut function in general, and epithelial function in particular, are well known (65). Moreover, it is increasingly apparent that the gastrointestinal epithelium can respond directly to both bacterial attachment and contact with bacterial toxins. Thus, infection with a variety of pathogens, including enteroinvasive bacteria (eg, Escherichia coli, Salmonella species, Yersinia enterocolitica) elicits the production of chemokines and proinflammatory cytokines from cultured human gastrointestinal epithelial cell lines (66-68). Similarly, Salmonella dublin infection can result in epithelial nitric oxide production via mobilization of nuclear factor $\kappa \mathrm{B}$ and tyrosine kinase activity (69). In addition, bacterial infection can elicit increased transepithelial neutrophil migration (70) and increased expression of adhesion molecules (eg, intracellular adhesion molecule 1) (71), and a gastric epithelial cell line when in- fected with $H$ pylori has been shown to express the immune costimulatory molecules B7-1 and B7-2 (72). Furthermore, infection with noninvasive enteropathogenic $E$ coli results in an epithelial signal transduction cascade and a rearrangement of the enterocytic cytoskeleton to form an actin-rich area underneath the site of the bacterial attachment (73). Functional correlates of this are increased paracellular permeability and deranged epithelial electrolyte transport (7476). Both effects can affect directed water movement, and 'loosening' of the paracellular permeation pathway may evoke inflammatory responses via enhanced uptake of luminal material that has bypassed normal epithelial processing. The increased paracellular permeability is not due to epithelial cell death, but rather to focal dilations in the perijunctional ring of filamentous actin and the tight junctionassociated protein, zonula occludens-1 (74).

In examining epithelial cell interactions with bacteria, an intriguing observation has been reported where the bacterium carries its own receptor to facilitate epithelial attachment. The enteropathic $E$ coli bacterium binds to the surface of epithelial cells via a tyrosine-phosphorylated protein designated $\mathrm{Hp} 90$. This sets in progress a cascade of events that leads to the development of a pedestal-structure, the attaching and effacing lesion and ultimately to increased epithelial permeability (74). It now seems that the $\mathrm{Hp} 90$ expressed in the host epithelial cell is of bacterial origin (77). If similar scenarios are applicable to other species of bacteria, this will have a radical effect on how epithelial cell interactions with bacterial pathogens are viewed.

Bacterial toxins (and certain other products) can evoke a spectrum of signal transduction events in epithelial cells. For instance, Clostridium difficile toxins A and B, Vibrio cholerae zonula occludens toxin and Bacteroides fragilis enterotoxin can increase the permeability of confluent epithelial monolayers in vitro and/or elicit the production of proinflammatory chemokines (78-82). Phospholipase $\mathrm{C}$ from Clostridium perfringens can modulate the arachidonic acid cascade in intestinal epithelial cells, leading to increased production of platelet-activating factor (83). When epithelial MHC II expression is increased, as is typical during active inflammation, the enterocyte is capable of presenting bacterial superantigens to $T$ cells, leading to activation as characterized by increased proliferation and cytokine production (84).

The above data are from in vitro studies that allow direct assessment of the effect of the bacteria/bacterial products on the enterocyte in the absence of other cell types. Caution must be used when extrapolating in vitro results to in vivo results (85); however, in situ studies have clearly shown epithelial activation (ie, production of messenger molecules and increased expression of accessory molecules) during inflammation. Consequently, the enterocyte is identified as an active component in immune responses, responding to bacteria pathogens (invasive and noninvasive) and bacterial products, and with the potential to elicit an inflammatory response.

Recognition of the immune function of the epithelium, in conjunction with its ideal location for oral drug delivery, 
highlights the enterocyte as an attractive target for antiinflammatory therapies. Extrinsic modulation of the gut epithelium's response to bacteria requires precise knowledge of the signalling cascades that occur in response to infection, and strategic points therein that can be modulated by pharmacologics. For example, both protein kinase $\mathrm{C}$ and myosin light chain kinase are important in the loss of epithelial barrier function following exposure to the verotoxin-producing E coli strain O157:H7 (86). Indeed, infection with this organism can be confused with Crohn's disease (87). Additionally, bacterial infection or immune mediators evoked by bacterial products have been found to activate epithelial nuclear factor $\kappa \mathrm{B}(88)$; increase cytosolic calcium, inositoltriphosphate and phosphotyrosine protein levels (89); activate mitogen-activated protein kinase pathways (90); and mobilize signal transducers and activators of transcription proteins $(91,92)$ in in vitro model systems. If epithelial cell function is important in the regulation of enteric inflammatory diseases, and considerable data are available to support this hypothesis (93), then knowledge of the signalling pathways evoked in response to bacteria or bacterial products will be critical to understanding the pathophysiological mechanism(s) of these disorders (Figure 1C).

As a final example of the intricate interplay that can occur among the epithelium, inflammation, cytokine signalling and bacteria, it has been shown that transgenic mice that overexpress IL-7 develop colitis (94). Also, IL-7 is an important mediator in the microflora-dependent colitis that develops in animals that lack functional $\mathrm{T}$ and $\mathrm{B}$ cells (ie, RAG-2 knockout mice) (95). Moreover, in vitro studies show not only that epithelial cells are a source of IL-7 (that can modulate mucosal $\mathrm{T}$ cell responses) (96), but also that epithelial IL-7 receptor expression can be upregulated following bacterial invasion (97).

\section{CLINICAL PERSPECTIVE}

Given the long-standing postulate that Crohn's disease is caused by an infectious agent, it is not surprising that antibiotics have a similar history as that of anti-inflammatory therapy $(98,99)$. Much interest has been and continues to be shown in metronidazole (Flagyl, Rhône-Poulenc Rorer, Ville St Laurent, Quebec) (100) as a treatment for Crohn's disease. (The effectiveness of other antibiotics such as ciprofloxacin [Cipro, Bayer Inc, Etobicoke, Ontario] and clarithromycin [Biaxin, Abbott Laboratories, St Laurent, Quebec] are being explored).

Currently, the merits of antibiotic therapy in IBD is a highly controversial issue with advocates both for and against antibiotic use as first line therapy in treating Crohn's disease (100). This debate is typified by a pair of recent commentaries where the authors reviewed virtually identical clinical data and drew diametrically opposed conclusions. One assessment indicated that in the light of current treatments, "the use of antibiotics as primary therapy should strongly be considered" (101). Contrarily, Dr Feagan's (102) interpretation of the same data (considering study design, statistical analysis and change in Crohn's disease activity in- dex) led to the conclusion that while "we should not abandon the concept of targeting drug therapy towards the enteric flora...[the current] data suggest that antibiotics have little efficacy" in the treatment of Crohn's disease. Bearing in mind the risk of evolving bacterial antibiotic resistance and the chance of antibiotic-associated diarrhea caused either by disruption of the natural gut flora (103) or possibly by direct effects on the epithelium (104), antibiotics do appear to be effective, at least in alleviating disease symptomatology in a subpopulation of sufferers of Crohn's disease. However, the available data are insufficient to allow firm conclusions about the global effectiveness of antibiotic treatment in Crohn's disease. It is generally acknowledged that larger randomized controlled trials are required to resolve this controversy. Furthermore, the value of antibiotic therapy needs to be considered in terms of the clinical goal that is, are antibiotics a cure for gut inflammation, a treatment for specific aspects or complications associated with active disease (eg, perineal disease [105]), a method to alleviate disease symptomatology or a maintenance therapy to reduce the recurrence of disease relapse?

In modulating gut flora to benefit the patient, the use of probiotics (natural flora with low or no pathogenicity) is an additional therapeutic strategy to combat food allergy (106), various bacterial infections (107) and gut inflammation $(108,109)$. Preliminary data have been presented showing that Lactobacillus species can significantly reduce the spontaneous colitis that develops in IL-10-deficient mice (110). Probiotics are a novel and attractive alternative to traditional antibiotic therapies; however, the study of probiotics is in its infancy, and there are obvious problems in attempting to manipulate extrinsically a complex ecosystem such as the human gut lumen by introducing foreign organisms.

\section{CONCLUSIONS}

In this overview, data have been presented that illustrate an association among bacteria, bacterial products, aberrant immune responses and enteric inflammation. However, the chicken and egg conundrum persists, and it remains unclear whether idiopathic gut disorders are of bacterial etiology or whether another defect facilitates an inappropriate response to the commensal microflora and thereby exaggerates existing disease. Resolution of this issue may ultimately be central to defining a cure for IBD. Moreover, there is increasing support for the use of antibiotics as an alternative or complement to current therapies, particularly in the context of treating complications associated with IBD and alleviating the disease symptoms in a cohort of patients with Crohn's disease. Furthermore, while it is premature to abandon the pursuit of an infective, transmissible cause of IBD, it must be acknowledged that the search thus far has been unsuccessful. Consequently, it may be appropriate to de-emphasize identification of a specific pathogen and focus research efforts on assessing the impact of ubiquitous commensal bacterial products on gut form and function, and consider the effect of these agents on nontraditional immune cells such as the epithelium (Figure 1). Finally, knowledge of how bacteria and 
bacterial products can influence intestinal physiology, combined with data relating to epithelial permeability defects, immune dysfunction and any genetic propensity to develop disease, may be the key to understanding chronic disorders such as IBD and irritable bowel syndrome, on a patient-bypatient basis.

ACKNOWLEDGEMENTS: Studies referred to from the authors laboratory were conducted with operating grants from the Medical Research Council of Canada and the Crohn's and Colitis Foundation of Canada. The comments of Dr G Tougas (McMaster University, Hamilton), Dr PM Sherman (Hospital for Sick Children, University of Toronto) and Mrs B McGlinchey (McMaster University) on this manuscript are gratefully acknowledged.

\section{REFERENCES}

1. Abrams G. Microbial effects on mucosal structure and function. Am J Clin Nutr 1977;30:1880-6.

2. Savage D. Gastrointestinal microflora in mammalian nutrition. Ann Rev Nutr 1986;6:155-78.

3. Rook GAW, Stannford JL. Give us this day our daily germs. Immunol Today 1998;19:113-6.

4. Sartor RB. Current concepts of the etiology and pathogenesis of ulcerative colitis and Crohn's disease. Gastroenterol Clin North Am 1995;24:475-507.

5. Sartor RB. The role of enteric microflora in the pathogenesis of intestinal inflammation and arthritis. Aliment Pharmacol Ther 1997;11(Suppl 3):17-23.

6. Elson CO, Sartor RB, Tennyson GS, Riddell RH. Experimental models of inflammatory bowel disease. Gastroenterology 1995;109:1344-67.

7. Sadlack B, Marz H, Schorle H, Schimpl A, Feller AC, Horak I. Ulcerative colitis like disease in mice with a disrupted interleukin-2 gene. Cell 1993;75:253-61.

8. Kuhn R, Lohler J, Rennick D, Rajewsky K, Muller W. Interleukin 10 deficient mice develop chronic enterocolitis. Cell 1993;75:263-74.

9. Powrie F, Leach MW, Mauze S, Caddle LB, Coffman RL. Phenotypically distinct subsets of $\mathrm{CD}^{+} \mathrm{T}$ cells induce or protect from chronic intestinal inflammation in C. B-17 scid mice. Int Immunol 1993;5:1461-71.

10. Davidson NJ, Leach MW, Fort MM, et al. T helper cell 1-type CD4 ${ }^{+}$ T cells, but not B cells, mediate colitis in interleukin 10 deficient mice. J Exp Med 1996;184:241-51.

11. Davidson NJ, Hudak SA, Lesley RE, Menon S, Leach MW, Rennick DM. IL-12, but not IFN- $\gamma$, plays a major role in sustaining the chronic phase of colitis in IL-10-deficient mice. J Immunol 1998;161:3141-51.

12. Ma A, Datta M, Margosian E, Chen J, Horak I. T cells, but not $\mathrm{B}$ cells, are required for bowel inflammation in interleukin-2 deficient mice. J Exp Med 1995;182:1567-72.

13. Simpson SJ, Mizoguchi E, Allen D, Bhan AK, Terhost C. Evidence that $\mathrm{CD}^{+}$, but not $\mathrm{CD}^{+} \mathrm{T}$ cells are responsible for murine interleukin-2-deficient colitis. Eur J Immunol 1995;25:2617-25.

14. Powrie F, Carlino J, Leach MW, Mauze S, Coffman RL. A critical role for transforming growth factor- $\beta$ but not interleukin 4 in the suppression of T helper type 1 mediated colitis by CD45RB ${ }^{\text {low }} \mathrm{CD}^{+}$ T cells. J Exp Med 1996;183:2669-74.

15. Panwala CM, Jones JC, Viney JL. A novel model of inflammatory bowel disease: mice deficient for the multiple drug resistance gene, mdrla, spontaneously develop colitis. J Immunol 1998;161:5733-44.

16. Yamada M, Ohkusa T, Okayasu I. Occurrence of dysplasia and adrenocarcinoma after experimental chronic ulcerative colitis in hamsters induced by dextran sulphate sodium. Gut 1992;33:1521-7.

17. Okayasu I, Hatakeyama S, Yamada M, Ohkusa T, Inagaki Y, Nakaya R. A novel method in induction of reliable experimental acute and chronic colitis in mice. Gastroenterology 1990;98:694-702.

18. Cong Y, Brandwien SL, McCabe RP, et al. CD4 ${ }^{+}$T cells reactive to enteric bacterial antigens in spontaneously colitic $\mathrm{C} 3 \mathrm{H} / \mathrm{HeJBir}$ mice: increased $\mathrm{T}$ helper cell type 1 response and ability to transfer disease. J Exp Med 1998;187:855-64.
19. Taurog J, Richardson J, Croft J, et al. The germfree state prevents development of gut and joint inflammatory disease in HLA-B27 transgenic rats. J Exp Med 1994;180:2359-64.

20. Rath HC, Herfarth HH, Ikeda JS, et al. Normal luminal bacteria, especially bacteroides species, mediate chronic colitis, gastritis, and arthritis in HLA-B27 / human $b_{2}$ microglobulin transgenic rats. J Clin Invest 1996;98:945-53.

21. Garcia-Lafuente A, Antolin M, Guarner F, et al. Incrimination of anaerobic bacteria in the induction of experimental colitis. Am J Physiol 1997;272:G10-5.

22. Duchmann R, Kaiser I, Hermann E, Mayet W, Ewe K, Zumbuschenfelde KHM. Tolerance exists towards resident intestinal flora but is broken in active inflammatory bowel disease (IBD). Clin Exp Immunol 1996;102:448-55.

23. Pirzer U, Schonhaar A, Fleischer B, Hermann E, Zumbuschenfelde KHM. Reactivity of infiltrating T lymphocytes with microbial antigens in Crohn's disease. Lancet 1991;338:1238-9.

24. Duchmann R, Marker-Hermann E, Meyer zum Buschenfelde KH. Bacteria-specific T cell clones are selective in their reactivity towards different enterobacteria or $H$. pylori and increased in inflammatory bowel disease. Scand J Immunol 1996;44:71-9.

25. Duchmann R, Schmitt E, Knolle P, Zumbuschenfelde KHM, Neurath M. Tolerance towards resident intestinal flora in mice is abrogated in experimental colitis and restored by treatment with interleukin-10 or antibodies to interleukin-12. Eur J Immunol 1996;26:934-8.

26. Mizoguchi A, Mizoguchi E, Chiba C, et al. Cytokine imblance and autoantibody production in TCR- $\alpha-/$ - mice with inflammatory bowel disease. J Exp Med 1996;183:847-56.

27. Mizoguchi A, Mizoguchi E, Chiba, Balk AK. Role of appendix in the development of inflammatory bowel disease in TCR- $\alpha$ mutant mice. J Exp Med 1996;184:707-15.

28. Mishina D, Katsel P, Brown ST, Gilberts ECAM, Greenstein RJ. On the etiology of Crohn's disease. Proc Natl Acad Sci USA 1996;93:9816-20.

29. Rowbotham D, Howdle P, Trejdosiewicz L. Peripheral cell mediated immune response to mycobacterial antigens in inflammatory bowel disease. Clin Exp Immunol 1995;102:456-61.

30. Cahill RJ, Foltz CJ, Fox JG, Dangler CA, Powrie F, Schauer DB. Inflammatory bowel disease: an immunity mediated condition triggered by bacterial infection with Helicobacter hepaticus. Infect Immun 1997;65:3126-31.

31. Shomer NH, Dangler CA, Schrenzel MD, Fox JG. Helicobacter bilisinduced inflammatory bowel disease in scid mice with defined flora. Infect Immun 1997;65:4858-64.

32. Weber P, Kock M, Heizmann WR, Scheulen M, Hartmann F. Microbic superinfection in relapse of inflammatory bowel disease. J Clin Gastroenterol 1998;1992:302-8.

33. Sartor RB, Cromartie WJ, Powell DW, Schwab JH. Granulomatous enterocolitis induced in rats by purified bacterial cell wall fragments. Gastroenterology 1985;89:587-95.

34. Klasen IS, Melief MJ, van Halteren AGS, et al. The presence of peptidoglycan-polysaccharide complexes in the bowel wall and the cellular responses to these complexes in Crohn's disease. Clin Immunol Immunopathol 1994;71:303-8.

35. Hazenberg MP, de Visser H, Bras MJ, Prins ME, van de Merwe JP. Serum antibodies to peptidoglycan-polysaccharide complexes from the anaerobic intestinal flora in patients with Crohn's disease. Digestion 1990;47:172-80.

36. Chester JF, Ross JS, Malt RA, Weitzman SA. Acute colitis produced by chemotactic peptides in rats and mice. Am J Pathol 1985;121:284-90.

37. Anton PA, Targan SR, Shanahan F. Increased neutrophil receptors for and response to the proinflammatory bacterial peptide-formylmethionyl-leucyl-phenylalanine in Crohn's disease. Gastroenterology 1989;97:20-8.

38. Rugtveit J, Brandtzaeg P, Halstensen TS, Fausa O, Scott H. Increased macrophage subset in inflammatory bowel disease: apparent recruitment from peripheral blood monocytes. Gut 1994;35:669-74.

39. Baldassano RN, Schreiber S, Johnston RB, Fu RD, Muraki T, MacDermott RP. Crohn's disease monocytes are primed for accentuated release of toxic oxygen metabolites. Gastroenterology 1993;105:60-6.

40. Webb SR, Gascoigne NRJ. T cell activation by superantigens. Curr Opin Immunol 1994;6:467-75.

41. Johnson HM, Torres BA, Soos JM. Superantigens: structure 
and relevance to human disease. Proc Soc Exp Biol Med 1996;212:99-109.

42. Blackman MA, Woodland DL. In vivo effects of superantigens. Life Sci 1995;57:1717-35.

43. Paliard X, West SG, Lafferty JA, et al. Evidence for the effects of a superantigen in rheumatoid arthritis. Science 1991;253:325-9.

44. Conrad B, Weldmann E, Trucco G, et al. Evidence for superantigen involvement in insulin dependent diabetes mellitus aetiology. Nature 1994;371:351-5.

45. Curtis N, Zheng R, Lamb Jr, Levin M. Evidence for a superantigen mediated process in Kawasaki disease. Arch Dis Childhood 1995;72:308-11.

46. Brocke S, Hausmann S, Steinman L, Wucherpfennig KW. Microbial peptides and superantigens in the pathogenesis of autoimmune diseases of the central nervous system. Semin Immunol 1998;10:57-67.

47. Posnett DN, Schmelkin I, Burton DA, August A, McGrath H, Mayer LF. T cell antigen receptor $\mathrm{V}$ gene usage: increases in $\mathrm{Vb} 8^{+} \mathrm{T}$ cells in Crohn's disease. J Clin Invest 1990;85:1770-6.

48. Gulwani-Akolkar B, Akolkar PN, Minassian A, et al. Selective expansion of specific T cell receptors in the inflamed colon of Crohn's disease. J Clin Invest 1996;98:1344-54.

49. Ogawa H, Ito K, Takeda H, et al. Universal skew of $\mathrm{T}$ cell receptor (TCR) Vb usage for Crohn's disease. Biochem Biophys Res Comm 1997;240:545-51.

50. Kay RA. The potential role of superantigens in inflammatory bowel disease. Clin Exp Immunol 1995;100:4-6.

51. van Prohaska J. Role of staphylococcal enterotoxin in the induction of experimental ileitis. Ann Surgery 1963;158:492-7.

52. Kent TH. Staphylococcal enterotoxin gastroenteritis in Rhesus monkeys. Am J Pathol 1965;48:387-407.

53. Merrill T, Sprinz H. The effect of staphylococcal enterotoxin on the fine structure of the monkey jejunum. Lab Invest 1968;18:114-23.

54. Lionetti P, Spencer J, Breese EJ, Murch SH, Taylor J, MacDonald TT. Activation of mucosal $\mathrm{Vb}^{+} \mathrm{T}$ cells and tissue damage in human small intestine by the bacterial superantigen, Staphylococcus aureus enterotoxin B. Eur J Immunol 1993;23:664-8.

55. McKay DM, Donnelly G, Takeda T. Immune activation by Yersinia pseudotuberculosis mitogen (YPM) causes increased epithelial permeability and is prevented by inhibition of prostaglandin synthesis. J Allergy Clin Immunol 1998;101:S192. (Abst)

56. McKay DM, Singh PK. Superantigen-activation of immune cells evokes epithelial (T84) transport and barrier abnormalities via interferon- $\gamma$ and tumour necrosis factor- $\alpha$. Inhibition of increased permeability, but not diminished secretory responses by transforming growth factor $\beta_{2}$. J Immunol 1997;159:2382-90.

57. Lu J, Philpott DJ, Saunders PR, Perdue MH, Yang P, McKay DM. Epithelial transport and barrier abnormalities evoked by superantigen-activated immune cells are inhibited by IL-10, but not IL-4. J Pharmacol Exp Ther 1998;287:128-36.

58. McKay DM, Benjamin M, Lu J. CD4 ${ }^{+} \mathrm{T}$ cells mediate superantigeninduced abnormalities in murine jejunal ion transport. Am J Physiol 1998;275:G29-38.

59. Benjamin MA, Lu J, Donnelly G, Dureja P, McKay DM. Changes in murine jejunal morphology evoked by the bacterial superantigen Staphyloccoccus aureus enterotoxin B are mediated by CD4 ${ }^{+} \mathrm{T}$ cells. Infect Immun 1998;66:2193-9.

60. Steiner TS, Lima AA, Nataro JP, Guerrant RL. Enteroaggregative Escherichia coli produce intestinal inflammation and growth impairment and cause interleukin-8 release from intestinal epithelial cells. J Infect Dis 1998;177:88-96.

61. McKay DM, Baird AW. Cytokine regulation of epithelial permeability and ion transport. Gut 1999;44:283-9.

62. Kagnoff MF, Eckmann L. Epithelial cells as sensors for microbial infection. J Clin Invest 1998;100:6-10.

63. Fiocchi C. Intestinal inflammation: a complex interplay of immune and nonimmune cell interactions. Am J Physiol 1997;273:G769-75.

64. Collins SM. The immunomodulation of enteric neuromuscular function: implications for motility and inflammatory disorders. Gastroenterology 1996;111:1683-99.

65. Perdue MH, McKay DM. Integrative immunophysiology in the intestinal mucosa. Am J Physiol 1994;267:G151-65.

66. Eckmann L, Reed S, Smith J, Kagnoff M. Entamoeba histolytica trophozoites induce an inflammatory cytokine response by cultured human cells through the paracrine action of cytolytically released interleukin-1 $\alpha$. J Clin Invest 1995;96:1269-79.

67. Jung HC, Echmann L, Yang S, et al. A distinct array of proinflammatory cytokines is expressed in human colon epithelial cells in response to bacterial invasion. J Clin Invest 1995;95:55-65.

68. Casola A, Estes MK, Crawford SE, et al. Rotavirus infection of cultured intestinal epithelial cells induces secretion of CXC and CC chemokines. Gastroenterology 1998;114:947-55.

69. Salzman AL, Eaves-Pyles T, Linn SC, Denenberg AG, Szabo C. Bacterial induction of inducible nitric oxide synthase in cultured human intestinal epithelial cells. Gastroenterology 1998;114:93-102.

70. Savkovic SD, Koutsouris A, Hecht G. Attachment of a noninvasive enteric pathogen, enteropathogenic Escherichia coli, to cultured human intestinal epithelial monolayers induces transmigration of neutrophils. Infect Immun 1996;64:4480-7.

71. Huang GT-J, Eckmann L, Savidge TC, Kagnoff MF. Infection of human intestinal epithelial cells with invasive bacteria upregulates apical intercellular adhesion molecule-1 (ICAM-1) expression and neutrophil adhesion. J Clin Invest 1996;98:572-83.

72. Ye G, Barrera C, Fan X, et al. Expression of B7-1 and B7-2 costimulatory molecules by human gastric epithelial cells: potential role in $\mathrm{CD}^{+} \mathrm{T}$ cell activation during Helicobacter pylori infection. J Clin Invest 1997;99:1629-36.

73. Ismaili A, Philpott DJ, McKay DM, Perdue MH, Sherman PM. Epithelial cell responses to shiga toxin-producing Escherichia coli infection. In: Kaper JB, O'Brien AD, eds. Excherichia coli 0157:H7 and Other Shiga Toxin-Producing E. coli Strains. Washington: American Society for Microbiology, 1998:213-25.

74. Philpott DJ, McKay DM, Sherman PM, Perdue MH. Infection of T84 cells with enteropathogenic Escherichia coli alters barrier and transport functions. Am J Physiol 1996;270:G634-45.

75. Spitz J, Yuhan R, Koutsouris A, Blatt C, Alverdy J, Hecht G. Enteropathogenic Escherichia coli adherence to intestinal epithelial monolayers diminishes barrier function. Am J Physiol 1995;268:G374-9.

76. Stein MA, Mathers DA, Yan H, Baimbridge KG, Finlay BB. Enteropathogenic Escherichia coli markedly decreases the resting membrane potential of Caco-2 and HeLa human epithelial cells. Infect Immun 1996;64:4820-5.

77. Kenny B, DeVinney R, Stein M, Reinscheid DJ, Frey EA, Finley BB. Enteropathogenic E. coli (EPEC) transfers its receptor for intimate adherence into mammalian cells. Cell 1997;91:511-20.

78. Hecht G, Pothoulakis C, LaMont JT, Madara JL. Clostridium difficile toxin A perturbs cytoskeletal structure and tight junction permeability of cultured human intestinal epithelial monolayers. J Clin Invest 1988;82:1516-24.

79. Hecht G, Koutsouris A, Pothoulakis C, LaMont JT, Madara JL. Clostridium difficile toxin $B$ disrupts the barrier function of $\mathrm{T}_{84}$ monolayers. Gastroenterology 1992;102:4416-23.

80. Fasano A, Baudry B, Pumplin D, Wasserman S, Tall B, Ketley J, Kaper J. Vibrio cholerae produces a second enterotoxin, which affects intestinal tight junctions. Proc Natl Acad Sci USA 1991;88:5242-6.

81. Wellis C, van de Westerlo E, Jechorek R, Feltis B, Wilkins T, Erlandsen S. Bacteroides fragilis enterotoxin modulates epithelial permeability and bacterial internalization by HT-29 enterocytes. Gastroenterology 1996;110:1429-39.

82. Mahida Y, Makh S, Hyde S, Gray T, Borriello S. Effect of Clostridium difficile toxin A on human intestinal epithelial cells: induction of interleukin 8 production and apoptosis after cell detachment. Gut 1996;38:337-47.

83. Gustafson C, Kald B, Sjodahl R, Tagesson C. Phospholipase C from Clostridium perfringens stimulates formation and release of platelet activating factor (PAF acether) in cultured intestinal epithelial cells (INT 407). Scand J Gastroenterol 1991;26:1000-6.

84. Aisenberg J, Ebert EC, Mayer L. T cell activation in human intestinal mucosa: the role of superantigens. Gastroenterology 1993;105:1421-30.

85. McKay DM, Philpott DJ, Perdue MH. In vitro models in inflammatory bowel disease research - a critical review. Aliment Pharmacol Ther 1997;11(Suppl 3):70-80.

86. Philpott DJ, McKay DM, Mak W, Perdue MH, Sherman PM. Signal transduction pathways involved in enterohemorrhagic Escherichia coli-induced alterations in T84 epithelial permeability. Infect Immun 1998;66:1680-7.

87. Ilnyckyj A, Greenberg H, Bernstein CN. Escherichia coli 0157:H7 infection mimicking Crohn's disease. Gastroenterology 1997;112:995-9.

88. Keates S, Hitti YS, Upton M, Kelly CP. Helicobacter pylori infection 
activates NF- $\mathrm{KB}$ in gastric epithelial cells. Gastroenterology 1997;113:1099-109.

89. Ismaili A, Philpott D, Dytoc M, Sherman P. Signal transduction responses following adhesion of verocytotoxin producing Escherichia coli. Infect Immun 1995;63:3316-26.

90. Hobbie S, Chen LM, Davis RJ, Galan JE. Involvement of the mitogen-activated protein kinase pathways in the nuclear responses and cytokine production induced by Salmonella typhimurium in cultured intestinal epithelial cells. J Immunol 1997;159:5550-9.

91. Reinecker H, MacDermott RP, Mirau S, Dignass A, Podolsky DK. Intestinal epithelial cells both express and respond to interleukin 15. Gastroenterology 1996;111:1706-13.

92. Brokenshire J, Botelho F, Richards CD, McKay DM. Mobilization of epithelial STAT-1 in response to mediators released from bacterial superantigen-activated immune cells. Gastroenterology 1998;114:A1131. (Abst)

93. Toy LS, Yio XY, Lin A, Honig S, Mayer L. Defective expression of gp180, a novel CD8 ligand on intestinal epithelial cells, in inflammatory bowel disease. J Clin Invest 1997;100:2062-71.

94. Watanabe M, Ueno Y, Tomoharu Y, et al. Interleukin 7 transgenic mice develop chronic colitis with decreased interleukin 7 protein accumulation in the colonic mucosa. J Exp Med 1998; 187:389-402.

95. von Freeden-Jeffry U, Davidson N, Wiler R, Fort M, Burdach S, Murray R. IL-7 deficiency prevents development of a non-T cell non-B cell mediated colitis. J Immunol 1998;161:5673-80

96. Watanabe M, Ueno Y, et al. Interleukin 7 is produced by human epithelial cells and regulates the proliferation of intestinal mucosal lymphocytes. J Clin Invest 1995;95:2945-53.

97. Yamada K, Shimaoka M, Nagayama K, Hiroi T, Kiyono H, Honda T. Bacterial invasion induces interleukin-7 receptor expression in colonic epithelial cell line, T84. Eur J Immunol 1998;27:3456-60.

98. Sutherland L, Singleton J, Sessions J, et al. Double blind, placebo controlled trial of metronidazole in Crohn's disease. Gut 1991;32:1071-5.
99. Rutgeerts P, Hiele M, Geboes K, et al. Controlled trial of metronidazole treatment for prevention of Crohn's recurrence after ileal resection. Gastroenterology 1995;108:1617-21.

100. Greenbloom SL, Steinhart AH, Greenberg GR. Combination ciprofloxacin and metronidazole for active Crohn's disease. Can J Gastroenterol 1998;12:53-6.

101. Peppercorn MA. Antibiotics are effective therapy for Crohn's disease. Inflamm Bowel Dis 1997;3:318-9.

102. Feagan B. Antibiotics are not effective therapy for Crohn's Disease (time to remove the rose-colored glasses). Inflamm Bowel Dis 1997;3:314-7.

103. LaMont JT. Antibiotic associated diarrhea. Gastrointest Dis Today 1995;4:10-7.

104. Goldhill JM, Rose K, Percy WH. Effects of antibiotics on epithelial ion transport in the rabbit distal colon in vitro. J Pharm Pharmacol 1996;48:651-6.

105. Brandt LJ, Bernstein LH, Boley SJ, Frank MS. Metronidazole therapy for perineal Crohn's disease: a follow-up study. Gastroenterology 1983;83:383-7.

106. Majamaa H, Isolauri E. Probiotics: a novel approach in the management of food allergy. J Allergy Clin Immunol 1997;99:179-85.

107. Lewis SJ, Freeman AR. Review article: the use of biotherapeutic agents in the prevention and treatment of gastrointestinal disease. Aliment Pharmacol Ther 1998;12:807-22.

108. Malchow HA. Crohn's disease and Escherichia coli. A new approach in therapy to maintain remission of colonic Crohn's disease? J Clin Gastroenterol 1997;25:653-8.

109. Bengmank S. Ecological control of the gastrointestinal tract. The role of probiotic flora. Gut 1998;42:2-7.

110. Madsen KL, Doyle JS, Jewell LD, Tavernini MM, Fedorak RN. Lactobacillus species prevents colitis in interleukin 10 gene-deficient mice. Gastroenterology 1999;116:1107-14. 


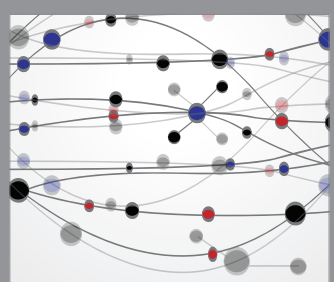

The Scientific World Journal
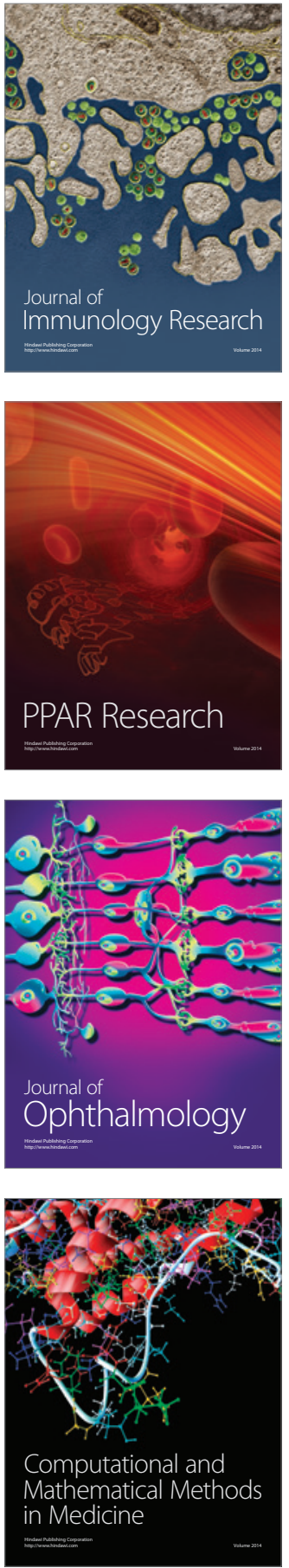

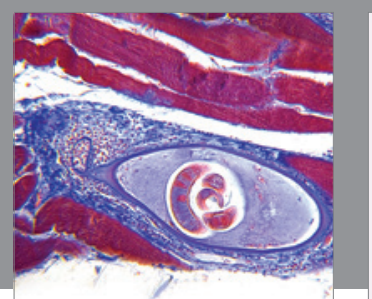

Gastroenterology Research and Practice

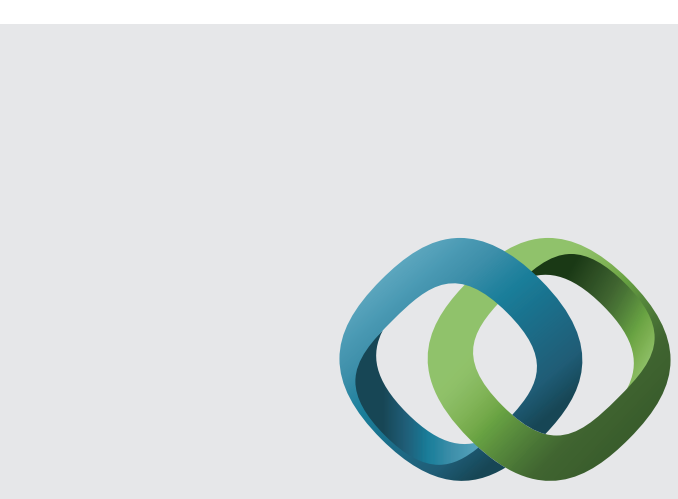

\section{Hindawi}

Submit your manuscripts at

http://www.hindawi.com
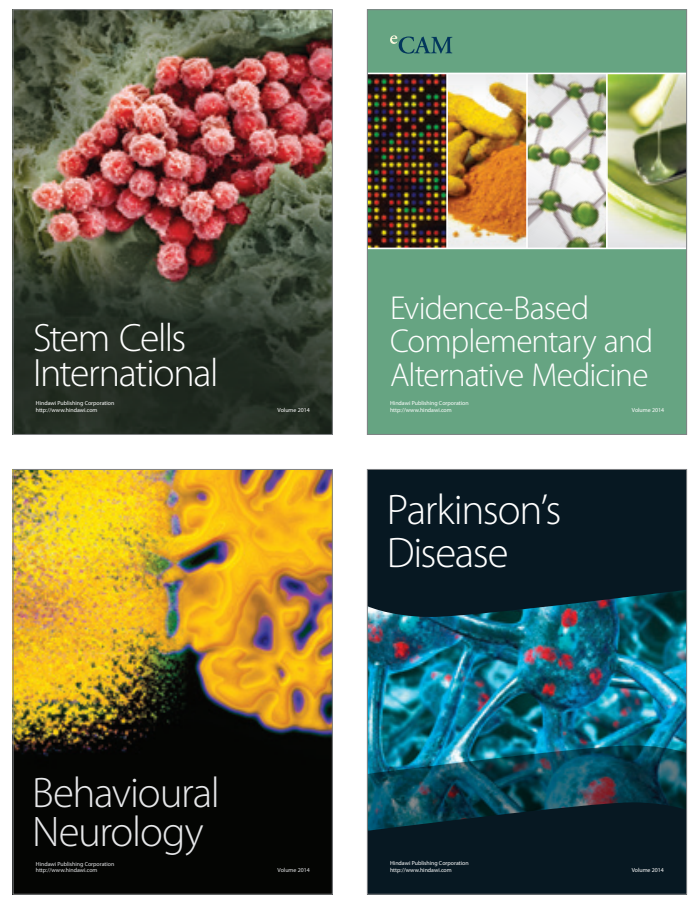
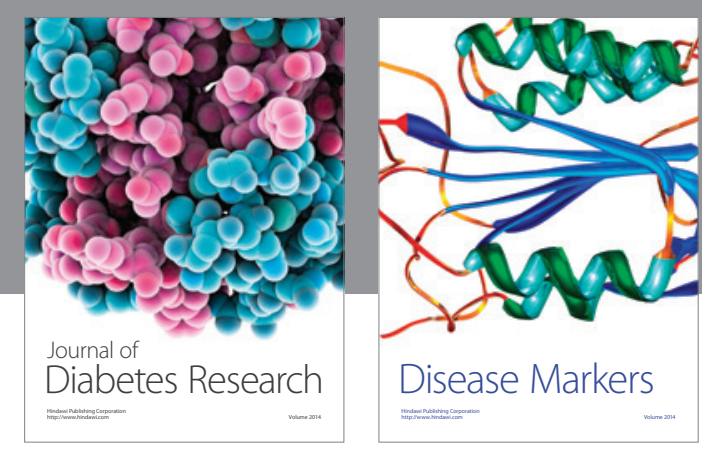

Disease Markers
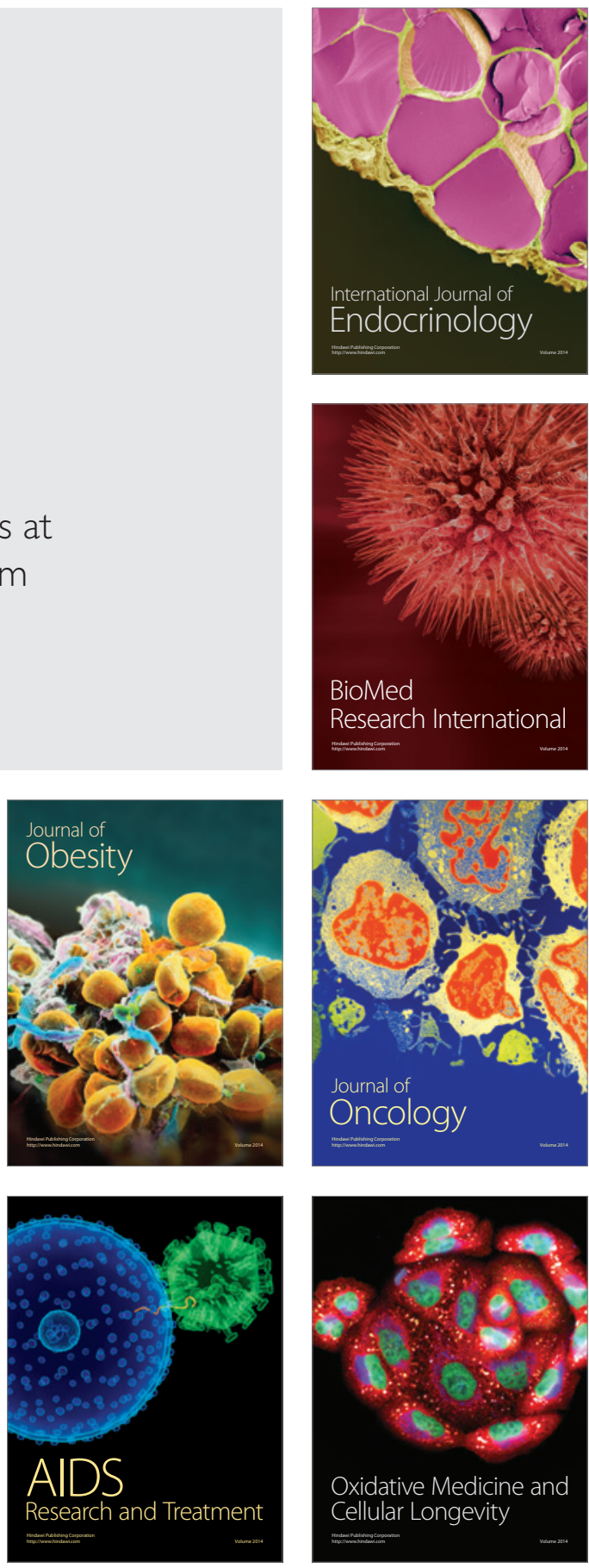